\title{
Size-assortative mating in a natural population of viviparus ater (gastropoda: prosobranchia) in lake Zürich, Switzerland
}

\author{
Staub, R ; Ribi, G
}

\begin{abstract}
The number of mating pairs, the size of the mating partners, and the distribution of individuals of Vivi-parus ater on a grid in Lake Zürich were recorded during one breeding season in 1990. There was positive assortative mating with respect to shell size. The proportion of copulating individuals ranged from $1 \%$ to $6 \%$ (average $3 \%$ ) of the active population at any one time. Individual snails copulated 60 times on average from April until November. Snails were abundant and copulated in shallow water close to the shore in Spring. They moved towards deeper areas in Autumn. V. ater copulated on all substrates at any depth (1-9 m) of the grid. The spatial distribution of copulations throughout the summer reflected the pattern of snail abundance
\end{abstract}

DOI: https://doi.org/10.1093/mollus/61.2.237

Posted at the Zurich Open Repository and Archive, University of Zurich ZORA URL: https://doi.org/10.5167/uzh-154798

Journal Article

Published Version

Originally published at:

Staub, R; Ribi, G (1995). Size-assortative mating in a natural population of viviparus ater (gastropoda: prosobranchia) in lake Zürich, Switzerland. Journal of Molluscan Studies, 61(2):237-247.

DOI: https://doi.org/10.1093/mollus/61.2.237 


\title{
SIZE-ASSORTATIVE MATING IN A NATURAL POPULATION OF VIVIPARUS ATER (GASTROPODA: PROSOBRANCHIA) IN LAKE ZÜRICH, SWITZERLAND
}

\author{
R. STAUB and G. RIBI \\ Zoologisches Museum der Universität Zürich, Winterthurerstrasse 190, 8057 Zürich, Switzerland
}

(Received 29 January 1993; accepted 14 November 1994)

\begin{abstract}
The number of mating pairs, the size of the mating partners, and the distribution of individuals of Viviparus ater on a grid in Lake Zürich were recorded during one breeding season in 1990 . There was positive assortative mating with respect to shell size. The proportion of copulating individuals ranged from $1 \%$ to $6 \%$ (average $3 \%$ ) of the active population at any one time. Individual snails copulated 60 times on average from April until November. Snails were abundant and copulated in shallow water close to the shore in Spring. They moved towards deeper areas in Autumn. $V$. ater copulated on all substrates at any depth $(1-9 \mathrm{~m})$ of the grid. The spatial distribution of copulations throughout the summer reflected the pattern of snail abundance.
\end{abstract}

\section{INTRODUCTION}

Mating frequency and the distribution of matings in time vary widely among species. Mating patterns have been interpreted as an adaptation to specific ecological conditions (Constantz, 1984), or to a small effective population size (Murray, 1964), or as a result of conflicting interests of males and females (Leonard \& Lukowiak, 1984; Trivers, 1985; Ward, Hemmi \& Rööli, 1992).

Males may increase their fitness by increasing the number of matings or the amount of sperm transferred to females relative to other males (Trivers, 1972), or by an optimal timing of copulations with respect to female receptivity (Cheng \& Burns, 1988; Drickamer, 1992). For females, optimizing the number of copulations is less straightforward, because the number of eggs a female can produce is limited. After the fertilization of the available eggs is ensured, the cost of additional copulations may exceed possible benefits. Costs of copulations include interference with other activities such as feeding (copulations in gastropods may last up to 36 hours; Lind, 1988; Tischler, 1973), a higher predation risk (Simmons, 1986; Pollard, 1975), physical damage by the act of copulation itself (Ward, Hemmi \& Rö̈sli, 1992), and parasite infection (Armstrong, 1977; Morand, 1988). Possible benefits of surplus copulations are the chance of finding better quality sperm (Curtsinger, 1991), the possibility of increasing the genetic variation of a clutch by using sperm of different males (Williams, 1975), or gaining additional resources from the ejaculate (Boggs \& Gilbert, 1979).

Viviparids are live-bearing freshwater prosobranch snails. The sexes are separate. In $V$. ater (Cristofori \& Jan), females kept without males did not reproduce (Trüb, 1990). In contrast to other Viviparus species (Browne, 1978; Stanczykowska, Magnin \& Dumouchel, 1971), females of $V$. ater do not grow older or larger than males. Both sexes can live for ten years or more (Ribi, Mutzner \& Gebhardt, 1986) and grow to approximately $45 \mathrm{~mm}$ in shell height. In Lake Zürich, female $V$. ater maintain a similar age-specific fecundity of approximately 9 female offspring per year between 2 and 6 years of age (Ribi, 1986). The offspring are born 6-11 $\mathrm{mm}$ in shell diameter after a gestation time of 3 to 9 months.

Males of the genus Viviparus produce two types of sperm, eupyrene and oligopyrene (Siebold, 1836). Oligopyrene sperm are infertile but rich in polysaccharides (Hanson, Randall \& Bayley, 1952). In $V$. contectus (Millet) they are absorbed by females, and may be invested in offspring (Dembski, 1968). We assume that this also applies to $V$. ater. If males were to make a significant energetic contribution to a female's reproductive output by providing sperm, one would expect copulations to be frequent. Frequent mating is, however, not essential for successful reproduction in $V$. ater. In a breeding experiment using caged snails, mated females continued to release offspring 
for two years after they had been isolated (Trub, 1990).

Size-assortative mating is expected to occur if males compete for females and if larger females have a higher fecundity than smaller ones (Ridley, 1983). Random mating with respect to size is expected if the encounter rate between potential mates is low (Parker, 1983). In $V$. ater, larger females produce more offspring than smaller ones (Ribi \& Gebhardt, 1986), and encounter rates are reasonably high as inferred from multiple matings of marked individuals in nature (Ribi \& Arter, 1986) and from the high population densities observed at many places (Barbato, 1971; De Bernardi, Ravera \& Oregioni, 1976; Trüb, 1990). Therefore we expect that males should prefer large females because of higher fecundity, and females should prefer large males if their ejaculate contains more energy than that of smaller males. The expected preferences by males and females may result in positive assortative mating by size, which we call size-assortative mating.

In this study we recorded the mating activity and the population density of Vivparus ater in Lake Zürich in Summer 1990. We asked the following questions:

1. Is there evidence of size-assortative mating?

2. How often do $V$. ater copulate in nature?

3. How are copulations distributed in time and space?

\section{METHODS}

A grid of 40 by $42 \mathrm{~m}$ (totalling $1680 \mathrm{~m}^{2}$ ) ranging from the shore to $9 \mathrm{~m}$ depth was set out near Goldbach, Lake Zürich, at the end of March 1990. The shore line consisted of large blocks of stone. The lake-bed in the shallow part of the grid consisted of gravel and stones, in the deeper part it consisted of sand and mud. The grid was at the same location as a previous one which was used to estimate offspring survival (Keller \& Ribi, 1993).

The grid was searched for copulating pairs of $V$. ater by two Scuba divers once a week from 4 April until 9 November 1990, with the exception of a break of three weeks starting on 23rd June. A pair was recorded copulating if one snail was observed holding on to another (Fig. 1a), or if the penis was observed to be introduced into the partners mantle cavity (Fig. 1b).

For each pair encountered, the location on the grid and the size class $(<=21,22-27,28-33,34-39$, $>=40 \mathrm{~mm}$ shell height) of the male and the female was recorded. The size classes were based on a sizeage survey made near Kilsnacht (some $2 \mathrm{~km}$ from the study site) during 1987/88, which showed that an age structure could be assigned to each size class (Fig. 2). The size class was determined by holding a calibrated stick next to each snail, to avoid disturbance of copulating pairs (data set $1, N=1136$ ). From August until November, in addition to being scored using the calibrated stick, the snails of 308 pairs were separated and measured to the nearst half $\mathrm{mm}$ using sliding calipers (data set 2). The first data set can show spatial differences or seasonal changes of the mating pattern, while the second set provides more accurate data on the relative size of mating partners. A comparison of the two data sets revealed that the assignment to a size class using the calibrated stick was correct in $83 \%$ of cases. There was an overestimation of size in $15 \%$ and an underestimation in $2 \%$ of the cases. Of the first 184 pairs encountered, the substrate type (hard or soft) was also recorded.

Dives were carried out in the morning between 0900 and $1200 \mathrm{~h}$. On three days in April-May and on three days in September, an additional dive was performed in the aftemoon of the same day. On those days, a metal stick was put into the sediment next to each copulating pair in the morning to avoid counting

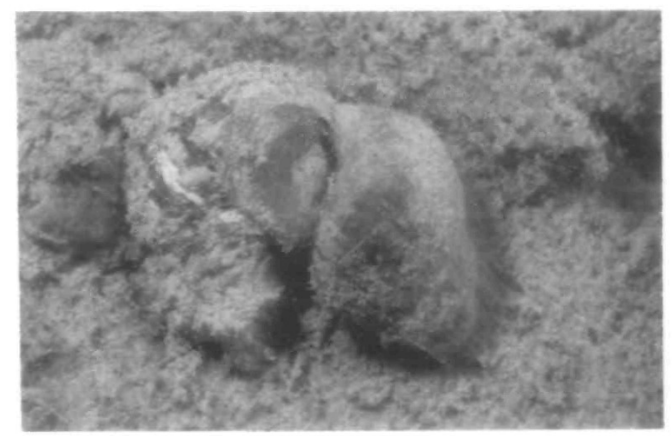

(a)

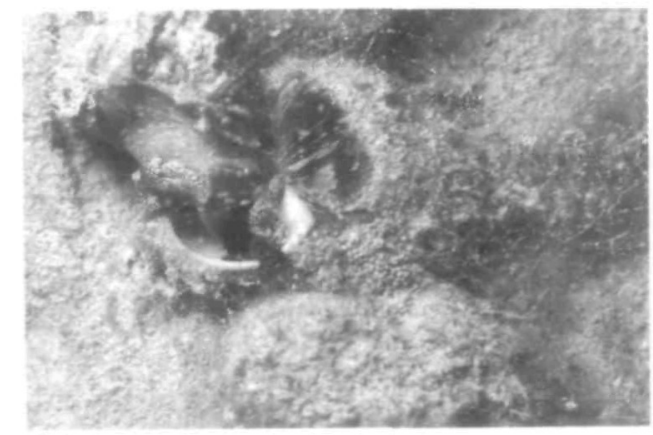

(b)

Fhgure 1. Copulations of Viviparus ater in nature. a) A male (right) holding on to a female; this is the most frequent mating position. b) Open position: the female is lying on the ground with the aperture of the shell exposed. The male has the penis introduced into the mantle cavity. 


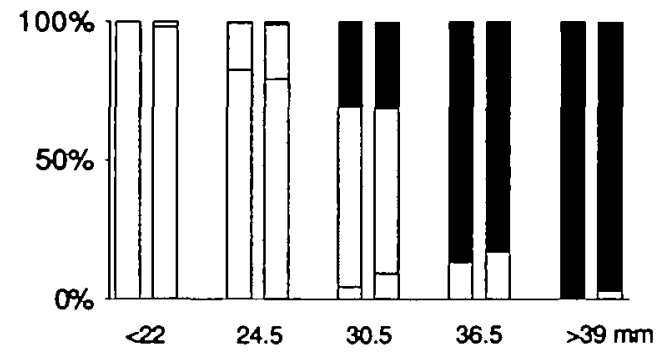

Figure 2. Age frequency distributions of Viviparus ater near Kusnacht, Lake Zürich, of the five size classes (labelled as upper or lower end or midpoints) used to estimate the sizes of mating partners. Left bars $=$ males $(\mathrm{N}=1468)$, right bars $=$ females $(\mathrm{N}=1475)$; white $=0+$, grey $=1+$, black $=2$ years and older.

the same pair twice and to obtain a rough estimate of copulation duration. Any pair recorded near a marker stick in the afternoon was assumed to be the same pair as that recorded in the morning. Dembsky, (1968) found that the average duration of copulation in $V$. contectus was $2 \frac{1}{2}$ hours, hence the chances of finding a different pair at the same place on the same day were low.

To obtain an estimate of the number of active snails on the grid throughout the study period, the snails were counted on every second row (parallel to the shore) of grid units on each dive, and the total number of snails counted multiplied by a factor of 2 . Thermometers were installed at $1.5,3,5.5,7$, and $8.5 \mathrm{~m}$ depths and the temperatures recorded during each dive.

The average number of copulations (C) per individual in one breeding season can be estimated by the formula $\mathrm{C}=(\mathrm{a} 1 \mathrm{p}) / \mathrm{d}$, where (a) is the daily period during which copulations may occur, measured in hours; (d) is the average duration of copulation measured in hours; (1) is the length of the breeding season measured in days; and (p) is the proportion of copulating snails observed at any one time. In a mating experiment in small artificial ponds using both $V$. ater and $V$. contectus, copulations occurred during 24 hours per day in both species. $V$. ater showed no consistent difference in mating frequency between day and night (Ribi, unpublished data). Hence we assume that the daily period during which copulations may occur (a) is 24 hours in natural populations of $V$. ater. The mating experiments in artificial ponds gave no indication that the duration of copulation is different between $V$. ater and $V$. contectus. We therefore use 2.5 hours, as observed by Dembski (1968) for $V$. contectus, as an average copulation duration for $V$. ater. In Lake Zuirich, the breeding season of $V$. ater is from early April until late October (Burla, 1972), resulting in a breeding season (1) of approximately 210 days. The proportion (p) of copulating snails observed at any one time was calculated by dividing the number of copulating snails by the total number of visible snails on the grid for each dive.

The data concerning the size of mating partners were analysed by linear regressions using the SAS program package (SAS Institute Inc., 1989). Because the size frequency distributions of $V$. ater were not the same in different depth zones (Fig. 3), a positive correlation of the sizes of mating partners could have arisen from the spatial zonation of snails of different sizes rather than as a consequence of size assortative mating. A second bias could have been introduced by vertical migrations of the snails (Table 1, Fig. 3). In order to remove the effects of the location on the grid and the time of the year, a multivariate regression was performed on each data set with the sizes of the two partners of a mating pair as the dependent variables and the two grid axes and the date of observation as independent variables. The residuals of the sizes of the two partners were then plotted against each other and analysed by linear regression.

\section{RESULTS}

\section{Size-assortative mating}

We have two data sets with regard to the shell size of mating pairs, i.e. one in which five size classes (class width $6 \mathrm{~mm}$ ) were recorded, from April until November (data set 1), and one in which the snails were measured to the nearest half $\mathrm{mm}$, from August until November (data set 2).

A significant positive correlation between the sizes of copulating individuals can indicate sizeassortative mating (Ridley, 1983). In both data sets there were significant positive correlations between the sizes of mating partners (Fig. 4), and also between their residuals after the effects of the location on the grid and of the

Table 1. Spatial and temporal pattern of the average density (ind $\mathrm{m}^{-2}$ ) of Viviparus ater on the grid in Summer 1990.

\begin{tabular}{lccccccc}
\hline & April & May & June & July & Aug. & Sept. & Oct. \\
\hline Boulder-zone & 0.52 & 6.00 & 2.11 & 0.39 & 0.52 & 0.20 & 0.17 \\
$1-3 \mathrm{~m}$ & 0.57 & 1.74 & 1.21 & 1.23 & 1.99 & 1.32 & 0.46 \\
$3-5 \mathrm{~m}$ & 0.59 & 1.14 & 0.69 & 1.10 & 2.16 & 2.63 & 3.27 \\
$5-7 \mathrm{~m}$ & 0.28 & 1.39 & 0.65 & 1.37 & 3.03 & 4.80 & 3.27 \\
$7-9 \mathrm{~m}$ & 0.22 & 1.46 & 1.33 & 1.43 & 2.12 & 3.73 & 3.39 \\
\hline
\end{tabular}



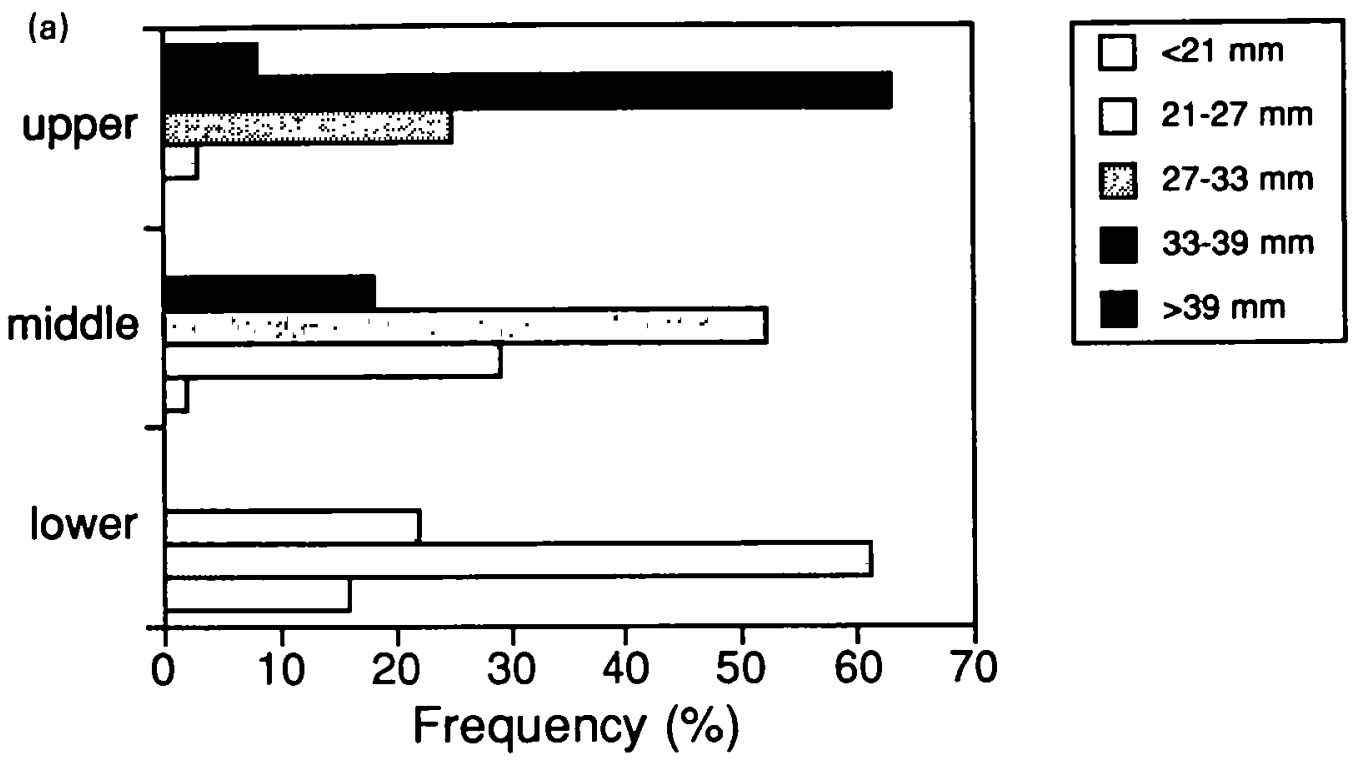

(b)


Figure 3. Size frequency distribution of Viviparus ater in the upper (1-3 m depth), middle (4-6 m), and lower (7-9 m) part of the grid in June (a) and August (b) 1990.

observation date had been removed (Table 2).

In data set 1 , the frequency of pairs in which both partners belonged to the same size class was between 40 and $45 \%$ at all times and all depth zones (Fig. 5). Pairs with larger females were more frequent than pairs with larger males in April (Fig. 5a) and in the upper third of the grid (Fig. 5b), while pairs with larger males outnumbered pairs with larger females from June until October and on the lower half of the grid. In data set 2 , pairs with larger males $(n=99$; difference $>3 \mathrm{~mm})$ were twice as frequent as pairs with larger females $(n=42)$. This may reflect the fact that small males never 


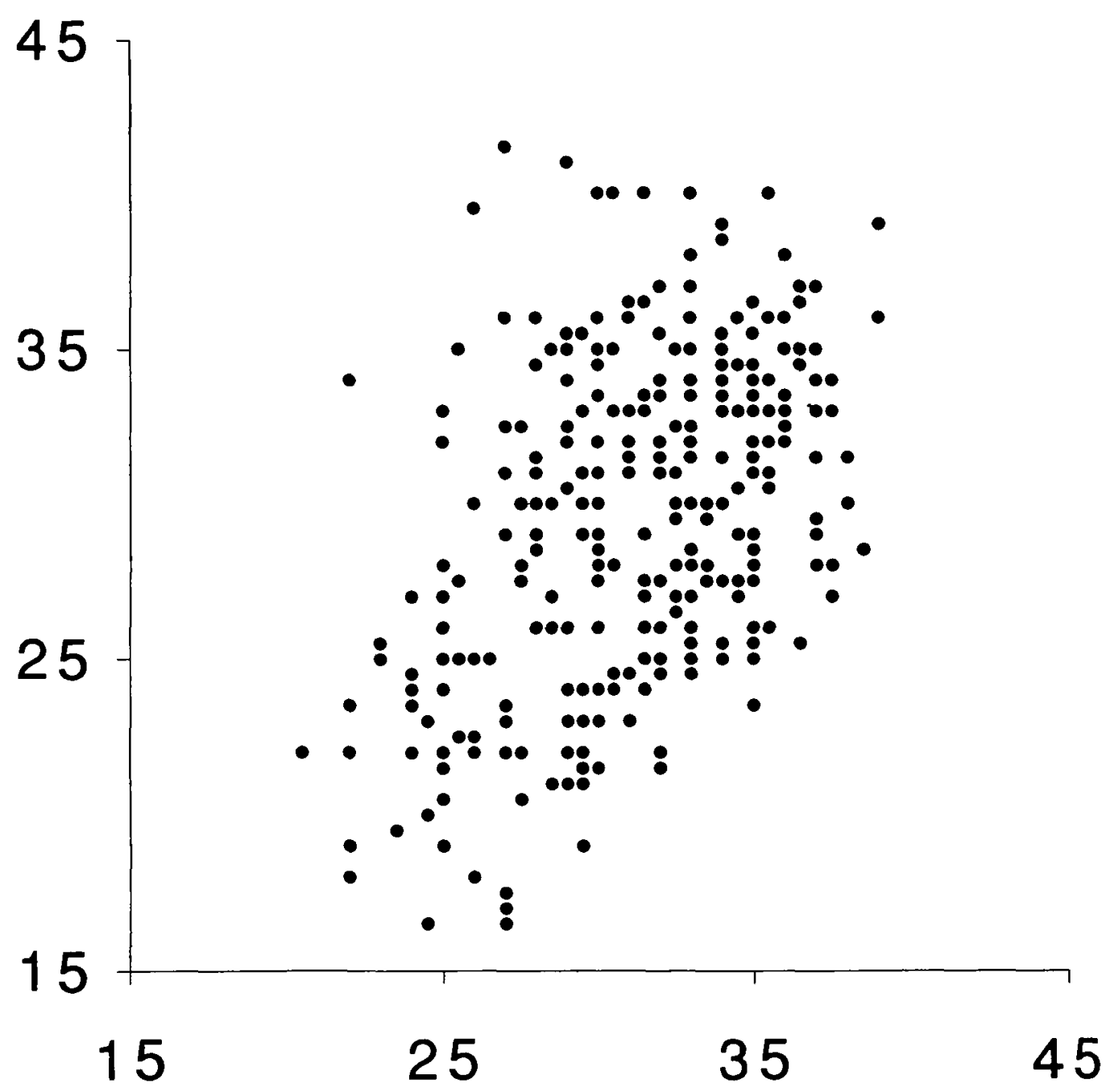

Figure 4. Shell height in $\mathrm{mm}$ of the partners of 308 mating pairs of Viviparus ater observed on the grid from August until November 1990 . Males on $x$-axis, females on $y$-axis.

Table 2. Linear regression of the residuals of the sizes of the two partners of a mating pair. The residuals were generated by multivariate regression on the sizes of the mating partners, with the vertical (depth) and the horizontal grid axes, and the date of observation as independent variables.

\begin{tabular}{|c|c|c|c|c|c|}
\hline & \multirow[t]{2}{*}{$\mathbf{N}$} & \multicolumn{2}{|c|}{ Sum of squares } & \multirow[t]{2}{*}{$\mathbf{F}$} & \multirow[t]{2}{*}{$\mathbf{P}$} \\
\hline & & Model & Error & & \\
\hline Date set 1 & 1136 & 83.45 & 459.57 & 205.2 & 0.0001 \\
\hline Date set 2 & 308 & 1042.20 & 3663.94 & 87.0 & 0.0001 \\
\hline
\end{tabular}

mated, while small females did (Fig. 6). Whether this should be interpreted as mate preference of females for larger males depends on the mating capability of small males. In the laboratory, $23 \mathrm{~mm}$ males were observed to mate. There were, however, no larger snails in the tank.

A wide range of size combinations of males and females was observed (Fig. 4), indicating that size assortative mating in $V$. ater is not due to physical incompatibility between partners of unequal size.

In both males and females of data set 1 , smaller snails (size classes 0 and $1=$ snails 
(a)

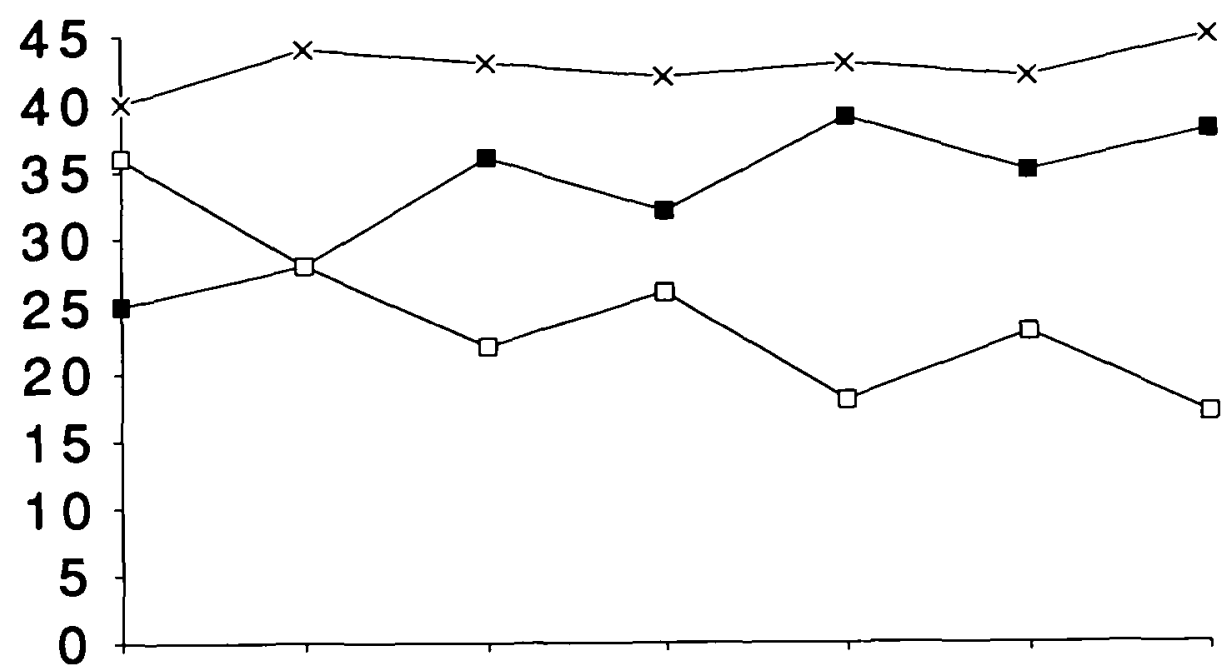

Apr. May Jun. Jul. Aug. Sep. Oct.

(b) 50

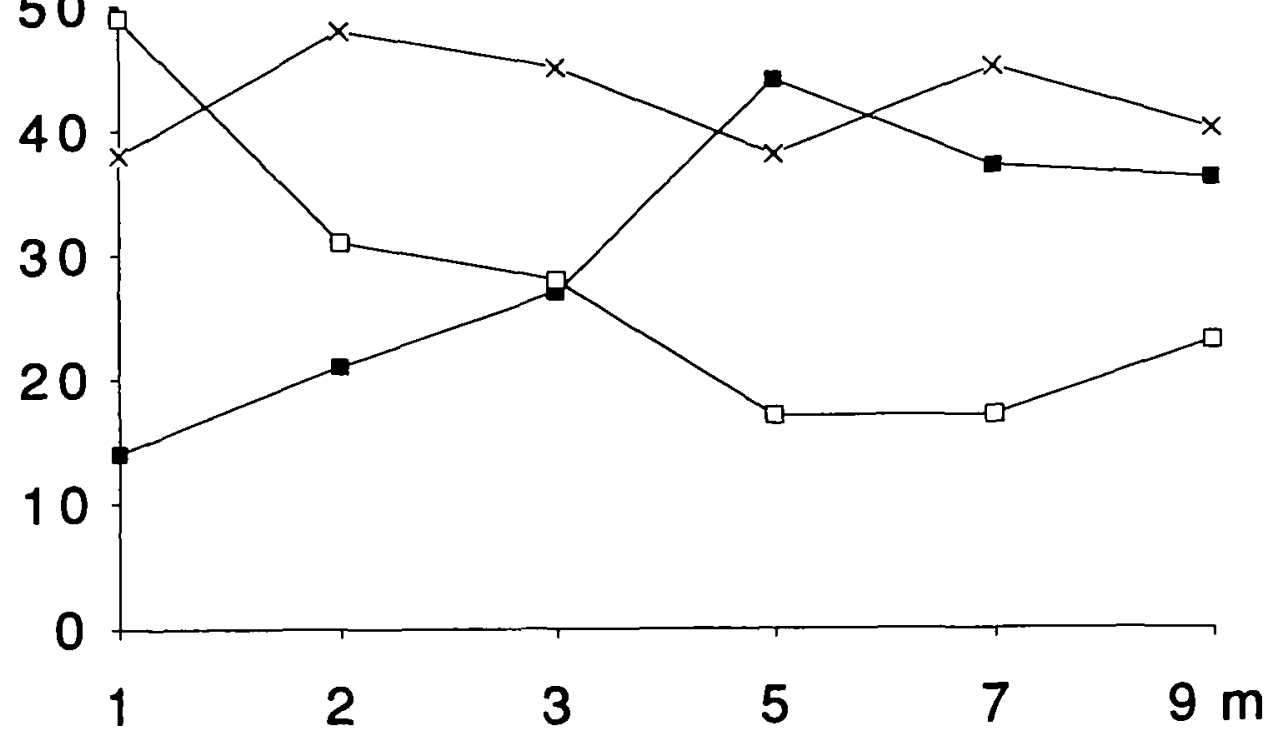

Pigure 5. Percentage of copulating pairs with larger males (black symbols), larger females (open symbols), and pairs in which both partners belong to the same size class $(--\times-)$, from April until October 1990 (a), and from the shore to $9 \mathrm{~m}$ depth (b).

smaller than $28 \mathrm{~mm}$ ) were observed copulating less often than expected from their relative frequency in the population observed in a previous study $\left(\mathrm{Chi}^{2}=318\right.$ for males and 271 for females, $D F=1, p<0.0001$ in both cases; Fig. $6)$. This can be interpreted in two ways. Smaller (younger) snails may mate less often on average, or their copulation duration may be shorter, reducing the probability of being detected by a diver. A shorter copulation duration of young as opposed to older adults has been reported for Achatina fulica (Tomiyama, 1994). 


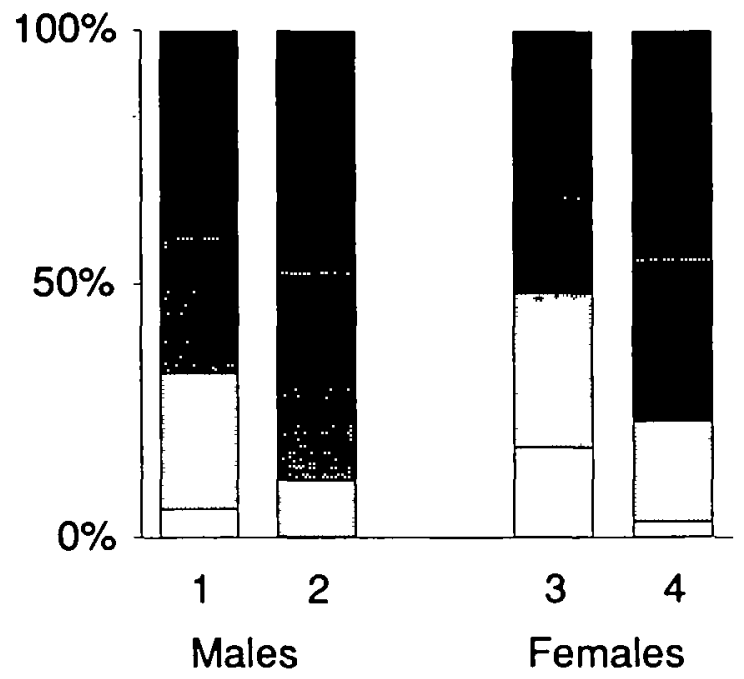

Figure 6. Proportions of five different size classes $(<=21,22-27,28-33,34-39,>=40 \mathrm{~mm}$ shell height; from white to black) of Viviparus ater in the population as reported by Keller \& Ribi, 1993 (bars 1 and 3), and in copulating pairs (bars 2 and 4 ), for males and females.

\section{Mating frequency}

$V$. ater copulated throughout their active period from April until early November. The proportion of copulating individuals ranged from 1 to $6 \%$ (average $3 \%$ ) of the active part of the population (i.e. the snails that are not buried in the sediment). It was highest in April and declined thereafter (Fig. 7). There was a positive linear relationship between the number of copulations and the number of snails observed $\left(R^{2}=0.975\right)$. The average copulation frequency per snail was 60.5 copulations per breeding season or one copulation every 3.47 days.

\section{Distribution of copulations in time and space}

Fig. 8 shows the spatial distribution of copulations. In April-May the majority of pairs were observed in the upper half of the grid. From June until August copulations were scattered over the entire area of the grid, while in September-October most copulations occurred in the lower half. This pattern reflects the seasonal distribution of the snails on the grid (Table 1), indicating that snails copulate in all parts of the grid during a breeding season. Copulations were observed on every substrate type present on the grid. Twenty five per-cent of the first 184 pairs were recorded on stones, the remaining $75 \%$ on mud. This was equivalent to the estimated proportions of hard and soft bottom available in the upper part of the grid, where the majority of these pairs were encountered. Hence the snails seem to mate indiscriminately with respect to substrate type.

The proportion of copulating snails was similar in the morning and in the afternoon in AprilMay, and slightly but not significantly $(p=0.13$, paired t-test, $\mathrm{df}=2, \mathrm{t}=2.50$ ) higher in the afternoon in September (Table 3). The average duration of copulation decreased from Spring to Autumn. In April, approximately one third of the copulating pairs were still in copula after 5 hours. By September, this figure had dropped to $7 \% \quad\left(\mathrm{Chi}^{2}=4.5, \mathrm{DF}=1, \mathrm{p}=0.033\right)$. The decrease in copulation duration was accompanied by a rise in water temperature from $8^{\circ} \mathrm{C}$ in April to $19^{\circ} \mathrm{C}$ in September.

Evidence for seasonal migration comes from the local population densities and the size frequency distributions. The highest local densities were recorded in the near shore area in May and between 5 and $7 \mathrm{~m}$ depth in September (Table 1). The size frequency distributions in three depth zones show an increase of the proportion of larger snails at greater depths from June to August (Fig. 3). This suggests that larger snails participate in the seasonal migrations towards deeper water in Autumn and towards the shore in Spring, while smaller (younger) snails tend to stay at greater depths throughout the Summer. Since young snails have a relatively thin shell, this behaviour may be interpreted as predator avoidance (Keller \& Ribi, 1993). 


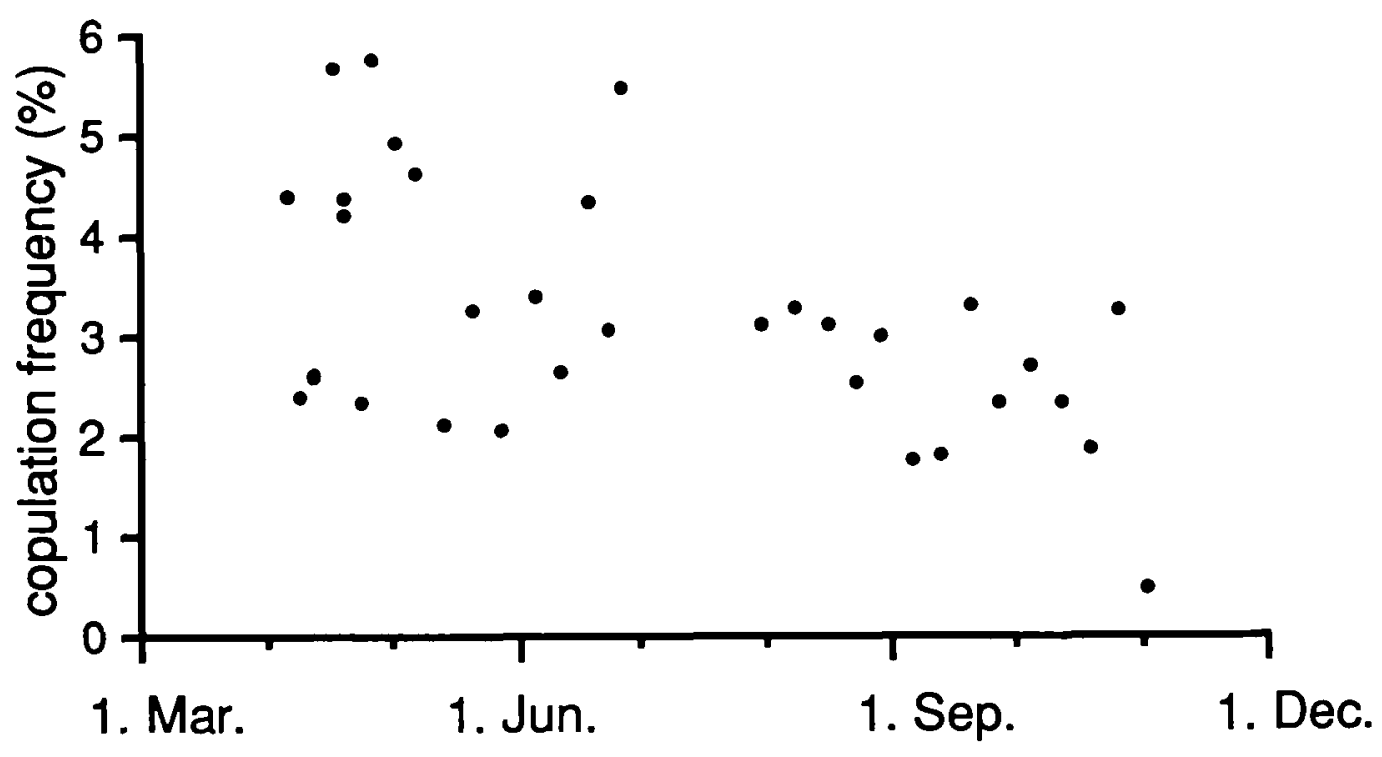

Figure 7. Frequency of copulations of Viviparus ater on the grid from 4 April to 11 November 1990, as the proportion of copulating snails to the number of snails observed on the grid.

Table 3. Copulation frequencies in the morning and afternoon, and proportion of copulations which lasted for more than 5 hours (lasting copulations), on 3 days in April-May and on 3 days in September 1990. $\mathbf{N}=$ total number of copulations observed in the mornings of 3 days.

\begin{tabular}{lccccc}
\hline & \multicolumn{2}{c}{ Proportion of copulating snails } & & $\begin{array}{c}\text { Lasting } \\
\text { copulations }\end{array}$ & $\mathrm{N}$ \\
\cline { 2 - 4 } & morning & afternoon & & \\
\hline April/May & $3.4 \%$ & $3.2 \%$ & $37 \%$ & 43 \\
September & $2.6 \%$ & $3.6 \%$ & $7 \%$ & 93 \\
\hline
\end{tabular}

\section{DISCUSSION}

\section{Size-assortative mating}

In gastropods, size-assortative mating has been documented in opisthobranchs (Crozier, 1918) and in prosobranchs (Edwards, 1968), while random mating may prevail in land snails (Baur, 1992). In the cowry Cypraea annulus, no correlation was observed between the sizes of mating males and females (Katoh, 1989).

$V$. ater can be considered a K-strategist relative to other gastropod species with which it may compete. It is larger, grows older, and invests more into individual offspring than any other gastropod living in Lake Zürich and central Europe (Calow, 1978). Its life history data are similar to those of vertebrate species in which female mate choice has been documented (Trivers, 1972). With respect to reproduction, quality seems to be more important than quantity in $V$. ater. Therefore, mate preference could be expected at least in females.

With respect to assortative mating we have made the following three observations which need to be explained. (1) Significant size assortative mating in both data sets; (2) both pairs with larger males and pairs with larger females occur frequently in nature; (3) pairs with larger females were more abundant in Spring, pairs with larger males were more abundant in Summer and Fall. We can think of three possible scenarios to explain these observations. (I) Snails prefer to mate with similar sized partners, possibly because of a good physical fit 
(a)

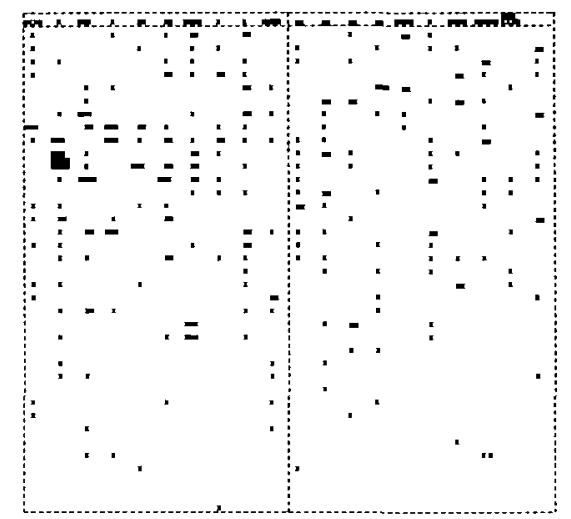

(b)

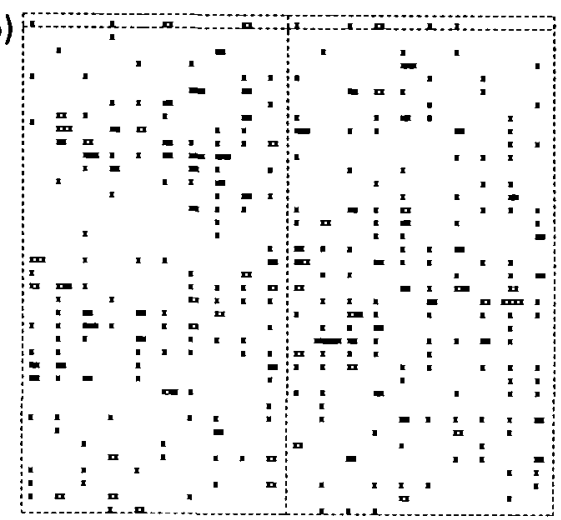

(c)

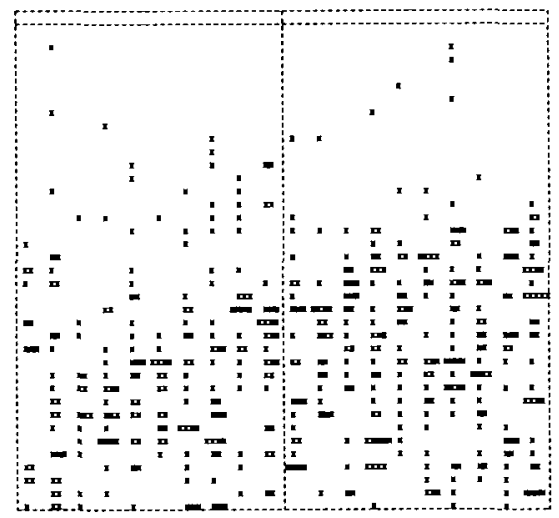

Figure 8. Spatial distribution of copulations of Viviparus ater on a grid of 40 by $42 \mathrm{~m}$, ranging from the shore (top) to $9 \mathrm{~m}$ depth, in April-May (a), in June-August (b) and in September-October (c), 1990.

which makes sperm transfer most efficient. (II) Both sexes prefer to mate with larger partners, because of an expected higher fitness return of larger partners. (III) There is no mate preference in $V$. ater: the size-assortative mating pattern observed has reasons other than mate preference. We now consider the plausibility of each of the three scenarios.

Scenario I: Observation 1 (size assortative mating) is consistent with Scenario I. Observations 2 to 3 weaken it, but are not inconsistent with it. They merely suggest that the preference to mate with an equally sized partner is not very strong.

Scenario II: Observation 1 (size assortative mating) is consistent also with Scenario II. Observation 2 (frequent occurrence of unequal pairs) suggests that both sexes can be rather opportunistic with respect to the size of the partner. Observation 3 (pairs with larger fe- males in Spring and larger males in Autumn) is consistent with Scenario II, if distribution changes of the snails on the grid (large females migrated downwards) are considered. Hence observation 3 may in part reflect differences in the size distributions of the sexes at different depth zones at different times of the year. Another explanation of observation 3 is that the motivation to mate with a larger partner may change over time, being higher for males in Spring and higher for females in Autumn. The two explanations are not mutually exclusive.

Scenario III: The significant size-assortative mating pattern observed could have arisen by local aggregation of similar sized individuals, for which, however, there is no supporting evidence.

In conclusion, we think that Scenario I or Scenario II applies, meaning that there is mate preference with respect to size in $V$. ater. However, we do not know whether snails prefer 
larger partners or partners of similar size, and whether mate preference occurs in both sexes.

\section{Mating frequency}

Multiple matings may contribute to an increase in fitness. In the land snail Arianta arbustorum (L.), snails which were allowed to re-mate had a higher fecundity than snails kept in isolation after having mated once (Baur, 1988). A high mating frequency may be typical for freshwater snails. In $V$. contectus, females were observed to mate with several males in one day (Dembski, 1968). A high mating frequency may be advantageous for females of Viviparus because of the extra energy acquired from sperm (Dembski, 1968). In Lymnaea auricularia (L.) and L. ovata (Draparnaud, 1805), 134 copulation-groups comprising 301 individuals (some groups consisted of more than 2 individuals) were collected during 8 dives in Lake Zürich (Burla \& Speich, 1971), suggesting a high mating frequency also in Lymnaea. The high mating frequency of $V$. ater contrasts with that of the land snail Helix pomatia L., which was observed to mate only a few times during a breeding season (Lind, 1988; Tischler, 1973).

\section{Distribution of matings in space and time}

Unlike in land snails, where mating is associated with the risk of desiccation (Prior, 1985) and predation (Pollard, 1975), the cost of copulations in $V$. ater appears to be low. This is reflected by the spatial and temporal distribution of copulations: we observed $V$. ater mating at any depth, on any substrate, at any time. Thus there is no indication that copulating individuals suffer higher predation rates than single snails.

\section{ACKNOWLEDGEMENTS}

We thank $\mathrm{H}$. Maag and the diving team of the Zoological Museum for help with the field work, $H$. Trüb for suggestions concerning data collection, A. Barbour and C. Rauter for help with data analysis, and N.J. Evans, M. Katoh, A.H. Porter, and P.H. Rudolph for comments on the manuscript.

\section{REFERENCES}

Armstrong, E. 1977. Transmission of Nosema kingi to offspring of Drosophila willistoni during copulation. Zeitschrift für Parasitenkunde, 53: 311-315.
Barbato, G. 1971. Studio sul comportamento stagionale di Viviparus ater (Crist. \& Jan) dei laghi d'Iseo e di Garda. Natura, 62: 65-74.

BAUR, B. 1992. Random mating by size in the simultaneously hermaphroditic land snail Arianta arbustorum: experiments and an explanation. Animal Behaviour, 43: 511-518.

BAur, B. 1988. Repeated mating and female fecundity in the simultaneously hermaphroditic land snail Arianta arbustorum. Invertebrate Reproduction and Development, 14: 197-204.

Boags, C.L. \& Gilbert, L.E. 1979. Male contribution to egg production in butterflies: evidence for transfer of nutrients at mating. Science, 206: 83-84.

Browne, R.A. 1978. Growth, mortality, fecundity, biomass and productivity of four lake populations of the prosobranch snail, Viviparus georgianus. Ecology, 59: 742-750.

Burla, H. 1972. Die Abundanz von Anodonta, Unio pictorum, Viviparus ater, Lymnaea auricularia und Lymnaea ovata im Zürichsee, in Abhängigkeit von der Wassertiefe und zu verschiedenen Jahreszeiten. Vierteljahresschrift der naturforschenden Gesellschafi Zürich, 117: 129-151.

Burla, H. \& SPEICH, C. 1971. Lymnaea auricularia und Lymnaea ovata im Zürichsee. Revue Suisse de Zoologie, 78: 549-556.

Calow, P. 1978. The evolution of life-cycle strategies in fresh-water gastropods. Malacologia, 17: 351364.

Cheng, K.M. \& Burns, J.T. 1988. Dominance relationship and mating behavior of domestic cocks. A model to study mate-guarding and sperm competition in birds. Condor, 90: 697-704.

ConstantZ, G.D. 1984. Sperm competition in poeciliid fishes. In: Sperm competition and the evolution of animal mating systems. R.L. Smith (ed.), 465-485. Academic Press, San Diego.

Crozier, W.J. 1918. Assortative mating in a nudibranch, Chromodoris zebra Heilprin. Journal of Experimental Zoology, 27: 247-292.

Curtsinger, J.W. 1991. Sperm competition and the evolution of multiple mating. American Naturalist, 138: 93-102.

De Bernardi, R., Ravera, O. \& Oregioni, B. 1976. Demographic structure and biometric characteristics of Viviparus ater Cristofori and Jan (Gasteropoda: Prosobranchia) from Lake Alserio (Northern Italy). Journal of Molluscan Studies, 42: 310-318.

Dembskı, W.J. 1968. Histochemische Untersuchungen über Funktion und Verbleib eu- und oligopyrener Spermien von Viviparus contectus (Millet 1813). Zeitschrift für Zellforschung, 89: 151179.

Drickamer, L.C. 1992. Oestrous female house mice discriminate dominant from subordinate males and sons of dominant from sons of subordinate males by odour cues. Animal Behaviour, 43: 868870.

Edwards, D.C. 1968. Reproduction in Olivella biplicata. Veliger, 10: 297-304. 
Hanson, J., Randall, J.T. \& Bayley, S.T. 1952. The microstructure of the spermatozoa of the snail Viviparus. Experimental Cell Research, 3: 65-78.

КАтон, M. 1989. Life history of the golden ring cowry Cypraea annulus (Mollusca: Gastropoda) on Okinawa Island, Japan. Marine Biology, 101: 227234.

Keller, G. \& Ribi, G. 1993. Fish predation and offspring survival in the prosobranch snail Viviparus ater. Oecologia, 93: 493-500.

LeonarD, J.L. \& Lukowiak, K. 1984. Male-female conflict in a simultaneous hermaphrodite resolved by sperm trading. American Naturalist, 124: 282 286.

LIND, H. 1988. The behaviour of Helix pomatia L. (Pulmonata, Gastropoda) in a natural habitat. Videnskabelige Meddelelser fra Dansk naturhistorisk Forening $i$ Khobenhavn, 147: 67-92.

Morand, S. 1988 . The developmental cycle of Nemhelix bakeri Morand and Petter (Nematoda, Cosmocercidae) parasite of the genital tract of Helix aspersa Mueller (Gastropoda, Helicidae). Canadian Journal of Zoology, 66: 1796-1802.

Murray, J. 1964. Multiple mating and effective population size in Cepaea nemoralis. Evolution, 18: 283-291.

Parker, G.A. 1983. Mate quality and mating decisions. In: Mate Choice. P. Bateson (ed.), 141-164. Cambridge University Press, Cambridge.

Pollard, E. 1975. Aspects of the ecology of Helix pomatia L. Journal of Animal Ecology, 44: 305329.

PrioR, D.J. 1985. Water regulatory behaviour in terrestrial gastropods. Biological Research, 60: 403424.

RıBı, G. 1986. Within-lake dispersal of the prosobranch snails, Viviparus ater and Potamopyrgus jenkinsi. Oecologia, 69: 60-63.

RiBi, G. \& Arter, H. 1986. Sex related difference of movement speed in the freshwater snail Viviparus ater. Journal of Molluscan Studies, 52: 91-96.

Ribi, G. \& Gebhardt, M. 1986. Age specific fecundity and size of offspring in the prosobranch snail, Viviparus ater. Oecologia, 71: 18-24.

Ribı, G., Mutzner, A. \& Gebhardt, M. 1986. Shell dissolution and mortality in the freshwater snail Viviparus ater. Schweizerische Zeitschrift für $\mathrm{Hy}$ drologie, 48: 34-43.

RidLeY, M. 1983. The Explanation of organic diversity. Clarendon Press, Oxford.

Sas InstTtute InC., 1989. SAS/STAT User's Guide, Version 6, Fourth Edition, Volume 1, Cary, NC: SAS Institute Inc., 943 pp.

SieboldD, C.T. 1836. Fernere Beobachtungen uber Spermatoz\&en der wirbellosen Thiere. 2. Die Spermatozöen der Paludina vivipara Müller. Archiv für Anatomie, Physiologie und Wissen. schaftliche Medizin, 2: 232-255.

Simmons, L.W. 1986. Female choice in the field cricket Gryllus bimaculatus. Animal Behavıour, 34: 1463-1470.

Stanczykowska, A., Magnin, E. \& Dumouchel, A., 1971. Etude de trois populations de Viviparus malleatus (Reeve) (Gastropoda, Prosobranchia) de la région de Montréal. I. Croissance, fécondité, biomasse et production annuelle. Canadian Journal of Zoology, 49: 1431-1441.

Tischler, W. 1973. Zur Biologie und Oekologie der Weinbergschnecke (Helix pomatia). Faunistischokologische Mitteilungen, 4: 283-298.

Tomiyama, K. 1994. Courtship behaviour of the giant African snail, Achatina fulica (Férussac) (Stylomatophora: Achatinidae) in the field. Journal of Molluscan Studies, 60: 47-54.

Trivers, R. 1985. Social evolution. Benjamin/ Cummings; Menlo Park, California.

Trivers, R. 1972. Parental investment and sexual selection. In: Sexual selection and the descent of man. B. Campbell (ed.), 136-179. Heinemann, London.

Trū́, H. 1990. Züchtung von Hybriden zwischen Viviparus ater und V. contectus (Mollusca, Prosobranchia) im Zürichsee und okkologische Untersuchungen in einer gemischten Population im Gardasee. Dissertation, Universităt Zürich.

WARd, P.I., Hemmi, J. \& RoOsli, T. 1992. Sexual conflict in the dung fly Sepsis cynipsea. Functional Ecology, 6: 649-653.

Williams, G.C. 1975. Sex and evolution. Princeton University Press: Princeton, New Jersey. 